\title{
Preliminary Phytochemical analysis and In vitro Antioxidant, FTIR Spectroscopy, Anti-diabetic activity of Acacia catechu ethanolic seed extract
}

\author{
Thangavelu Lakshmi ${ }^{*}{ }$, Rajendran Ramasamy ${ }^{2}$ and Rathinam Thirumalaikumaran ${ }^{3}$ \\ 'Department of Pharmacology, Saveetha Dental College and Hospitals, Chennai, India. \\ 2Department of R and D, Green Chem Herbal Extracts and Formulations, Bangalore, India. \\ 3Department of Pharmacognosy, Faculty of Pharmacy, Sree Ramachandra Medical College and Research Institute, chennai, India.
}

\begin{abstract}
Objective: To evaluate the preliminary phytochemical analysis and in vitro antioxidant activity, anti-diabetic effect of ethanolic seed extract of Acacia catechu against the alpha amylase and alpha glucosidase digestive enzymes in the pancreas and small intestine. Methods: Preliminary phytochemical analysis was done by adopting the method of Evans. Antioxidant assay is performed by DPPH, ABTS and FRAP assay, Anti diabetic activity was determined by modified method of miller, the extract at different concentrations was tested for mammalian alpha amylase and alpha glucosidase enzyme inhibitory assay under the controlled experimental conditions and subjected to determination of absorbance. Results: The present study reveals the presence of few secondary metabolites and the extract exhibits potent Antioxidant activity and a concentration dependent inhibition of Alpha amylase and Alpha glucosidase. Conclusion: From the present study it can be concluded that ethanolic seed extract of Acacia catechu possessed marked in vitro antioxidant and anti-diabetic effect. The effect was plausibly due to the presence of phenolic contents of Acacia catechu.
\end{abstract}

Key words: Acacia catechu seed, Antidiabetic, Antioxidant, Alpha-amylase, Alpha glucosidase, FTIR Spectroscopy, Phytochemical.

\section{SUMMARY}

- Acacia catechu seed exhibited significant anti-oxidant and free radical scavenging activity.

- Acacia catechu seed extract inhibits alpha amylase and alpha glucosidase enzyme thus possessing anti-diabetic activity.

- Acacia catechu seed is used in management of diabetes mellitus.

- Acacia catechu seed exhibited significant anti-oxidant and free radical scavenging activity.
- FTIR analysis reveals the presence of the functional groups in Acacia catechu seed extract.

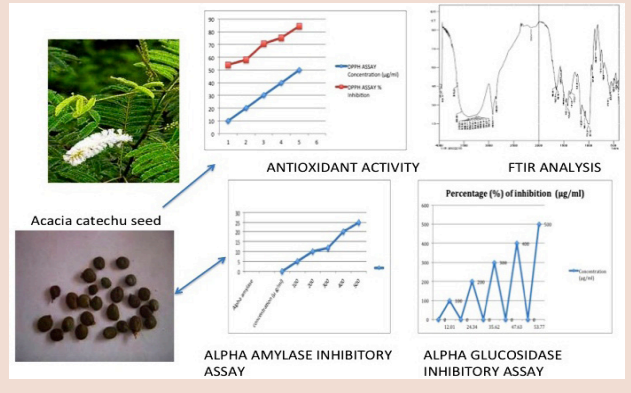

PICTORIAL ABSTRACT

Abbreviations used: DPPH: 2,2-diphenyl-1-picrylhydrazyl, TPC: Total phenolic content, TAC: Total Antioxidant content, TAE: Tannic acid equivalent, A. catechu: Acacia catechu, FRAP: Ferric ion reducing antioxidant power, ABTS: 2,2'-azinobis-(3-ethylbenzothiazoline-6-sulfonic acid), FTIR: Fourier Transform Infrared Spectroscopy.

Correspondence:

Ms. Thangavelu Lakshmi, Assistant professor, Department of Pharmacology, Saveetha Dental College and Hospitals, Chennai, T.N, India.

Phone no: 09884708887

Email: lakshmi085@gmail.com DOI : $10.5530 /$ pj.2015.6.7

\section{INTRODUCTION}

Antioxidants improve the quality of life by preventing the human body from various disorders like cancer, atherosclerosis, hypertension, cardiac failure, cognitive impairment, Alzheimer's disease which are caused by free radicals. ${ }^{1}$ These free radicals which cause oxidative damage is inhibited by antioxidants in plants and animals. Antioxidants contain enzymatic and non enzymatic system which is used to scavenge the free radicals during oxidative stress. ${ }^{2}$ Many plant extracts are rich in antioxidants like vitamin C, flavonoids, carotenoids, polyphenols which provides a nutritional value, and maintains proper physiological functions of the body.

Hyperglycemia in diabetes patients is of a serious concern today. Several factors may contribute to hyperglycemia in people with diabetes, including food and physical activity choices, illness, non-diabetic medications, or not taking enough glucose-lowering medication. It is essential to treat postprandial hyperglycemia, because if left untreated, hyperglycemia can become severe and lead to serious complications requiring emergency care, such as diabetic coma. In the long term, persistent hyperglycemia, even if not severe can lead to complications affecting vital organ functions of the body.
Management of hyperglycemia is achieved by the inhibition of carbohydrate hydrolyzing enzymes like alpha amylase and alpha glucosidase. ${ }^{3}$ These are termed as digestive enzymes that are mainly involved in digestion of carbohydrates and aid in intestinal absorption. Inhibiting alpha amylase and alpha glucosidase is a major goal in controlling the post prandial increase in blood sugar level. ${ }^{4}$

Herbal products have been used widely for management of diabetes mellitus. Various literatures revealed the use of herbal extracts in treatment of insulin dependent diabetes mellitus. ${ }^{5}$ Plant extracts rich in polyphenols possess good antioxidant activity and shows activity similar effects like insulin in the management of type 2 diabetes mellitus by inhibiting Pancreatic alpha amylase and Intestinal alpha glucosidase enzyme. ${ }^{6} \mathrm{Al}$ pha glucosidase inhibitors can be used as monotherapy in conjunction with an appropriate diabetic diet and exercise, or they may be used in conjunction with other anti-diabetic drugs. ${ }^{7}$

Acacia catechu belongs to the family fabaceae also known as black cutch and karungali in Tamil. In Kerala people drink it in boiling water to pre- 
vent digestive problems. Various part of the plant leaves, bark, heartwood possess diverse pharmacological actions for management of various disorders. ${ }^{8,9}$ The pharmacological activities in various parts of the plant has been extensively studied. Phytochemical constituents like Catechin, Epicatechin, Cyanidol, Quercetin, Epigallocatechin gallate, Rutin, Isorhamnetin, Taxifolin is found to be present in A.catechu. ${ }^{10}$ The various part of the extract reports the antipyretic, anti-inflammatory, antidiarrheal, hypoglycemic, hepatoprotective, antioxidant and antimicrobial activities including anti caries and anti plaque activity. ${ }^{11,12}$ Hence, in this study the antioxidant and anti diabetic activities of Acacia catechu ethanolic seed extract were measured systematically using different assays using a standard protocol and first time being reported so far.

\section{MATERIALS AND METHODS}

\section{Plant material collection and extraction}

Acacia catechu seeds were collected from Hosur, Tamil Nadu and were authenticated by Green Chem lab, Bangalore.

\section{Chemicals and reagents}

DPPH, BHA, Folin-Ciocalteu, Alpha glucosidase, Alpha amylase, Trypsin, Tris-Hcl buffer, P-nitro phenyl- glucopyranoside, dinitrosalicylic acid, starch were procured from Sigma Chemicals (USA). Other reagents like dimethyl sulfoxide (DMSO), sodium carbonate per chloric acid, sulphuric acid, sodium phosphate and ammonium molybdate were purchased from Merck (India).

\section{Preparation of ethanolic extract}

Seeds were shade dried for a week. Dried seeds were milled to fine powder. Powder was passed through 100 mesh sieve and stored in a sealed polythene bag $2.5 \mathrm{~kg}$ of powdered Acacia catechu seeds were extracted with 10 liters of Ethanol, at $65^{\circ} \mathrm{C}$ temperature, for 1 hour, in a 20 liter round bottom flask with Graham condenser attached. Condenser was cooled circulating with chilled water. After 1 hour of extraction, round bottom flask was cooled to room temp and the extract were filtered and collected. The Marc was extracted repeatedly with 10 liters of Ethanol, twice. The extracts were filtered and collected. The combined extracts was evaporated to dryness under reduced pressure in a Buchi Rotary Evaporator (Switzerland) at $65^{\circ} \mathrm{C}$, to obtain $150 \mathrm{~g}$ of powder extract. The w/w yield of the prepared extract was $6 \%$. The extractwere stored at $4^{\circ} \mathrm{C}$ until used.

\section{Preliminary phytochemical analysis}

The ethanolic extract so obtained from the dried seed powder of Acacia catechu, were tested for the presence and absence of the phytochemicals-Tannins, Phlobatannins, Saponins, Flavonoids, Terpenoids, Phenols, Cardiac glycosides and Steroids according to method described by Evans. ${ }^{13}$ The results were depicted in Table 1.

\begin{tabular}{|c|c|}
\hline Tannins & + \\
\hline Saponins & + \\
\hline Flavonoids & + \\
\hline Phlobatannins & - \\
\hline Phenols & + \\
\hline Terpenoids & - \\
\hline Cardiac glycosides & - \\
\hline Steroids & - \\
\hline
\end{tabular}

$+=$ Presence; -=Absence.

\section{Total phenolic content}

Folin-Ciocalteu method was followed for the determination of the total phenolic content of the plant extract. Distilled water $(500 \mu \mathrm{l})$ and Folin-Ciocalteu reagent $(100 \mu \mathrm{l})$ were added to $100 \mu \mathrm{l}$ of the plant extract and incubated for $6 \mathrm{~min}$ at room temperature. The final volume was made up to $3 \mathrm{ml}$ after addition of $1.25 \mathrm{ml}$ of $7 \%$ sodium carbonate. The absorbance was measured at $760 \mathrm{~nm}$ using UV-visible spectrophotometer (Cyber-Lab, USA) after an incubation period of $90 \mathrm{~min}$. The total phenolic content was expressed as milligrams of tannic acid equivalents per gram of dry weight (mg TAE/g DW) of the plant, using a standard plot of Tannic acid. ${ }^{14}$

\section{Total Antioxidant content}

The total antioxidant activity was estimated by phosphor molybdenum method. To the plant extract $(0.5 \mathrm{ml})$, a reagent solution $(0.6 \mathrm{M}$ sulphuric acid, $28 \mathrm{mM}$ sodium phosphate and $4 \mathrm{mM}$ ammonium molybdate) of 4.5 $\mathrm{ml}$ was added and the solution was maintained in a boiling water bath at $95^{\circ} \mathrm{C}$ for $90 \mathrm{~min}$. The solution was cooled to room temperature and the absorbance was measured at $695 \mathrm{~nm}$ using UV-visible spectrophotometer. The total antioxidants in the plant were expressed as mg TAE/g DW of the plant extract.

\section{Free radical DPPH scavenging assay}

The ethanolic seed extract of $A$. catechu was taken at various concentrations $(10,20,30,40$ and $50 \mu \mathrm{g} / \mathrm{ml})$, in small tubes and made up to 1 $\mathrm{ml}$ using methanol. $1 \mathrm{ml}$ of $0.01 \mathrm{mM} \mathrm{DPPH}$ dissolved in methanol was added to all the test concentrations and maintained in the dark for 30 min, at room temperature. The absorbance of the solutions was read at $517 \mathrm{~nm}$. The percentage inhibition and the $\mathrm{IC}_{50}$ values were calculated with DPPH as the control and butylated hydroxyanisole (BHA) as the reference. The concentration in $\mu \mathrm{g}$ of dry material per $\mathrm{ml}$ of solvent $(\mu \mathrm{g} / \mathrm{ml})$ that inhibits the formation of DPPH radicals by $50 \%$ is defined as $\mathrm{IC}_{50}$ value. $^{15}$

$$
\% \text { Inhibition }=\frac{\text { (Absorbance of the control }(\mathrm{Ac})-\mathrm{Abs} \text { orbance of the sample }(\mathrm{As})}{\text { Absorbance of the control(Ac) }} \times 100
$$

\section{Ferric Reducing antioxidant power (FRAP) assay}

$1 \mathrm{ml}$ of plant extract, $2.5 \mathrm{ml}$ phosphate buffer (of $0.2 \mathrm{M}, \mathrm{pH} 7$ ) and $1 \%$ potassium ferricyanide $(2.5 \mathrm{ml})$ were mixed and incubated at $50^{\circ} \mathrm{C}$ for 30 min. To the solution, $2.5 \mathrm{ml}$ of $10 \%$ trichloroacetic acid was added and centrifuged at $6500 \mathrm{rpm}$ for $10 \mathrm{~min}$. Distilled water $(2.5 \mathrm{ml})$ and $0.5 \mathrm{ml}$ of $0.1 \% \mathrm{FeCl}_{3}$ were added to $2.5 \mathrm{ml}$ of the supernatant. The absorbance of the solution was measured at $700 \mathrm{~nm}$ using UV-visible spectrophotometer. The reducing ability of the plant was evaluated in terms of percentage by relating to the standard, $\mathrm{FeSO}_{4}$.

$$
\% \text { Inhibition }=\frac{\text { (Absorbance of the control }(\mathrm{Ac})-\mathrm{Abs} \text { orbance of the sample }(\mathrm{As})}{\mathrm{Abs} \text { orbance of the control }(\mathrm{Ac})} \times 100
$$

\section{[2,2'-Azino-bis(3-ethylbenzothiazoline-6-sulphonic acid)] ABTS assay}

A solution of $7 \mathrm{mM}$ ABTS [2,2'-azino-bis(3-ethylbenzothiazoline-6-sulphonic acid)] and $2.45 \mathrm{mM}$ potassium persulphate was incubated in the dark for 12-16 h, after which the solution was diluted with ethanol till the absorbance reached $0.7 \pm 0.02$ at $734 \mathrm{~nm}$. $1 \mathrm{ml}$ of the diluted solution was mixed with $100 \mu \mathrm{l}$ of plant extract and the absorbance was evaluated at $734 \mathrm{~nm}$ after $6 \mathrm{~min}$. The percentage reduction against ABTS was calculated with reference to the standard, Tannic acid. 


\section{FTIR spectroscopy ${ }^{16}$}

The infrared spectrum was recorded from $\mathrm{KBr}$ discs on a FTIR Perkin Elmer model 16 PC spectrophotometer (Perkin Elmer, Waltham, USA). Absorption maxima $\left(\check{\mathrm{H}}_{\max }\right)$ were reported in wavenumbers $\left(\mathrm{cm}^{-1}\right)$. The spectra were used to determine organic groups indicative of the main classes of secondary metabolites. It reveals the presence of Hydroxyl, Alkanes, Amides, Alkyl halides, Aliphatic amines, Nitro groups.

\section{Anti diabetic activity}

\section{a-Amylase inhibitory assay}

The $\alpha$-Amylase $(0.5 \mathrm{mg} / \mathrm{ml})$ was premixed with extract at various concentrations $(100-500 \mu \mathrm{g} / \mathrm{ml})$ and starch azure as a substrate was added as a $0.5 \%$ starch solution to start the reaction. The reaction was carried out at $37^{\circ} \mathrm{C}$ for $5 \mathrm{~min}$ and terminated by addition of $2 \mathrm{ml}$ of DNS (3,5-dinitrosalicylic acid) reagent. The reaction mixture was heated for $15 \mathrm{~min}$ at $100^{\circ} \mathrm{C}$ and diluted with $10 \mathrm{ml}$ of distilled water in an ice bath. $\alpha$-amylase activity was determined by measuring at $540 \mathrm{~nm}$ using spectrophotometer (Perkin Elmer Lambda 25 UV-VIS). A control reaction was carried out without the test sample. The experiments were repeated thrice using the same protocol.

The $\%$ a-amylase inhibitory activity is calculated by the following formula;

$$
(\% \text { Inhibition })=\frac{\text { Control OD-Sample OD }}{\text { Control OD }} \times 100
$$

The $\mathrm{IC}_{50}$ value was defined as the concentration of the sample extract to inhibit $50 \%$ of alpha amylase activity under assay condition.

\section{In vitro inhibition of a-glucosidase}

The enzyme $a$-glucosidase inhibitory activity was determined by premixing $\alpha$-glucosidase (0.07 Units) with $100-500 \mu \mathrm{g} / \mathrm{ml}$ of extract. Then $3 \mathrm{mM}$ p-nitro phenyl glucopyranoside was added as a substrate. ${ }^{17}$ This reaction mixture was incubated at $37^{\circ} \mathrm{C}$ for $30 \mathrm{~min}$ and the reaction was terminated by addition of $2 \mathrm{ml}$ of sodium carbonate. The a-glucosidase activity was determined by measuring the p-nitro phenyl release from $\mathrm{p}$ nitro phenyl glucopyranoside at $400 \mathrm{~nm}$. A control reaction was carried out without the test sample. The $\%$ a-glucosidase inhibitory activity is calculated by the following formula.

$$
(\% \text { Inhibition })=\frac{\text { Control OD-Sample OD }}{\text { Control OD }} \times 100
$$

The $\mathrm{IC}_{50}$ value was defined as the concentration of the sample extract to inhibit $50 \%$ of alpha glucosidase activity under assay condition.

\section{Statistical analysis}

Experimental values are expressed as mean \pm SD. Values are means of three independent analyses of the sample \pm standard deviation $(n=3)$. Independent Sample t-test was carried out for statistical comparison. Statistical significance was considered to be indicated by a ${ }^{*} \mathrm{p}$ value $<0.05$ in all cases.

\section{RESULT AND DISCUSSION}

\section{Determination of total phenolic content (TPC), and total antioxidant content (TAC)}

TPC and TAC of Acacia catechu seed extract were determined in terms of tannic acid equivalent (TAE). TPC with folin-ciocalteu method was reported as $47.32 \pm 0.29 \mathrm{mg}$ TAE/g DW, TAC with phospho molybdenum method was reported as $20.07 \pm 0.23 \mathrm{mg}$ TAE/ DW of the plant. ${ }^{18}$ Table 2 represents the results of TPC and TAC recorded..$^{18}$
Table 2: TPC and TAC of the ethanolic seed extract of Acacia catechu

\begin{tabular}{ll}
\hline Acacia catechu ethanolic seed & \\
\hline Total phenolic content $(\mathbf{m g}$ TAE$/ \mathbf{g} \mathrm{DW})$ & $47.32 \pm 0.29 \mathrm{mg}$ TAE/g DW \\
Total antioxidant content $(\mathbf{m g}$ TAE$/ \mathbf{g ~ D W})$ & $20.07 \pm 0.23 \mathrm{mg}$ TAE/ DW \\
\hline Values are mean \pm SD of triplicate samples.
\end{tabular}

\section{DPPH free radical scavenging assay}

The free radical scavenging ability of the ethanolic seed extract of Acacia catechu was carried out using DPPH. The $\mathrm{IC}_{50}$ value of the extract was recorded as $10-\mu \mathrm{g} / \mathrm{ml}$. herbal extracts with IC $_{50}$ values above $30 \mu \mathrm{g} / \mathrm{ml}$ are generally considered as non antioxidants. ${ }^{19}$ Table 3 shows the results of DPPH free radical scavenging activity of Acacia catechu seed extract

\begin{tabular}{|c|c|}
\hline Concentration $(\mu \mathrm{g} / \mathrm{ml})$ & \% Inhibition \\
\hline 10 & 54.11 \\
\hline 20 & 57.89 \\
\hline 30 & 71.00 \\
\hline 40 & 75.56 \\
\hline 50 & 84.44 \\
\hline \multicolumn{2}{|l|}{$\mathrm{IC}_{50}(\mu \mathrm{g} / \mathrm{ml})$} \\
\hline Sample & $<10$ \\
\hline BHA & 25.78 \\
\hline
\end{tabular}
tested at different concentrations.

The present study reveals that ethanolic seed extract of Acacia catechu of the Asian region showed better free radical scavenging activity (10 $\mu \mathrm{g} / \mathrm{ml})$. This might be due to the presence of strong biologically active components such as phenols and polyphenols, etc., which show remarkable activity against free radicals. ${ }^{20}$ Lower the $\mathrm{IC}_{50}$ value higher will be the antioxidant free radical scavenging ability. When compared with BHA, the plant showed better $\mathrm{IC}_{50}$ value and this can be potentially used as a natural antioxidant.

\section{Ferric reducing antioxidant power (FRAP) assay}

In FRAP assay, the complex containing ferric ions is converted to ferrous ions due to the action of reducing agents antioxidants, thereby generating chromogenic complex. ${ }^{21}$ The present study reveals the ability of Acacia catechu ethanolic seed extract to reduce the ferric ions (52.36\%).

\section{2,2'-Azino-bis(3-ethylbenzothiazoline-6-sulphonic acid (ABTS) assay}

Stable radicals of ABTS are generated when ABTS is mixed with potassium persulphate and incubated under dark conditions. Spectrometric evaluation at $734 \mathrm{~nm}$ (the characteristic wavelength for the ABTS radicals), showed that the extract scavenged the radicals to a higher extent (97.93\%).

The antioxidant assays performed represent the potential inhibition of the products of lipid oxidation as well as the ABTS radicals by Acacia catechu ethanolic seed extract. However, the plant exhibited low activity against the ferric ions in the FRAP assay. The differences in the different assays performed might be attributed to the different mechanisms involved. ${ }^{22}$

The results examined for DPPH free radical scavenging assay is presented in Figure 1. FRAP and ABTS assays is presented in Figure 2. TAE and TPC is presented in Figure 3. 


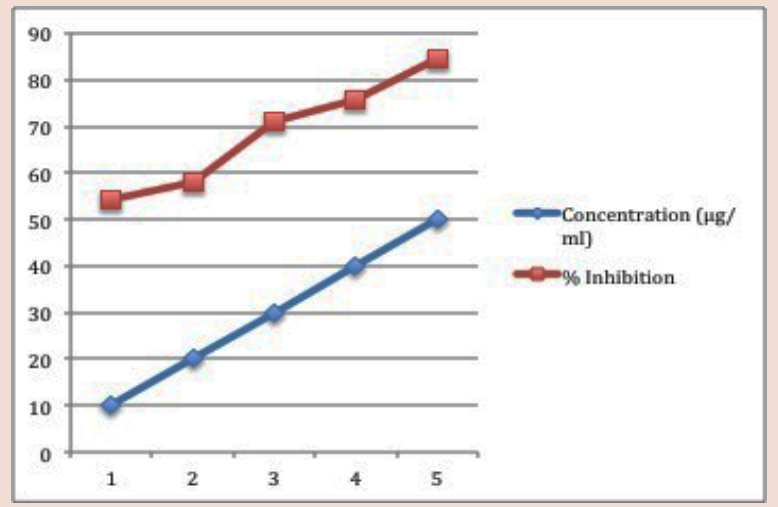

Figure 1: DPPH Assay of Acacia catechu seed

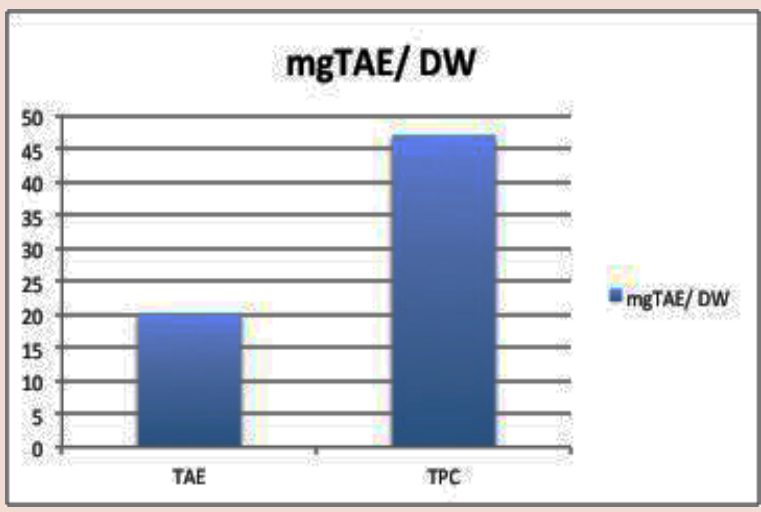

Figure 3: TAE, TPC of Acacia catechu seed

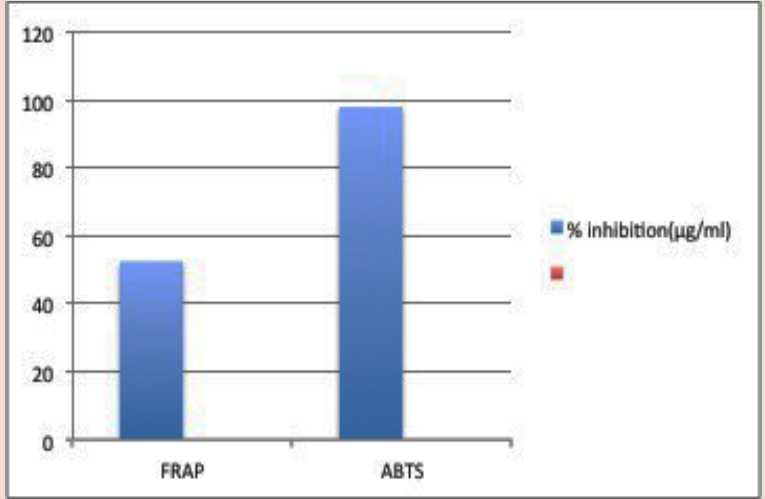

Figure 2: FRAP, ABTS Assay of Acacia catechu seed

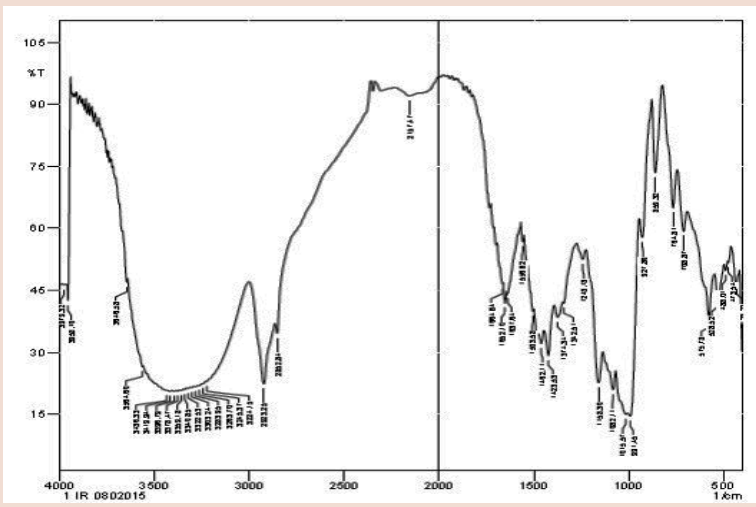

Figure 4: FTIR Spectroscopy of Acacia catechu seed

Table 4 :FTIR Spectroscopy

\begin{tabular}{ccccccc}
\hline Peak & Intensity & Corr.Inte & Base (H) & Base (L) & Area & Corr. Area \\
\hline 400.25 & 30.214 & 1.603 & 413.75 & 399.28 & 6.078 & 0.143 \\
428.22 & 46.399 & 0.882 & 430.14 & 419.54 & 3.387 & 0.016 \\
473.54 & 51.666 & 0.981 & 476.44 & 460.04 & 4.502 & 0.099 \\
488.01 & 49.81 & 1.819 & 495.73 & 477.4 & 5.414 & 0.162 \\
528.52 & 43.342 & 6.47 & 545.88 & 496.69 & 16.304 & 1.566 \\
575.78 & 38.538 & 8.443 & 593.14 & 546.84 & 16.626 & 1.611 \\
708.87 & 89.247 & 8.52 & 742.63 & 689.58 & 10.094 & 1.059 \\
764.81 & 64.946 & 14.775 & 821.71 & 743.59 & 8.802 & 2.748 \\
859.32 & 73.411 & 18.873 & 877.65 & 822.68 & 4.503 & 2.738 \\
927.8 & 57.81211 .707 & 944.2 & 878.61 & 9.745 & 1.843 & \\
991.45 & 14.544 & 11.34 & 1004.96 & 945.16 & 34.709 & 4.779 \\
1015.57 & 15.013 & 1.846 & 1067.65 & 1005.92 & 46.399 & 2.759 \\
1082.11 & 20.966 & 5.457 & 1135.16 & 1068.61 & 40.036 & 2.904 \\
1158.3 & 22.625 & 13.69 & 1224.85 & 1136.12 & 40.274 & 5.71 \\
1243.18 & 52.483 & 2.884 & 1274.04 & 1225.82 & 12.881 & 0.574 \\
1342.51 & 41.882 & 1.225 & 1347.34 & 1275 & 21.772 & 0.142 \\
1374.34 & 38.458 & 3.248 & 1391.7 & 1348.3 & 17.304 & 0.861 \\
1423.53 & 29.187 & 8.55 & 1444.75 & 1392.66 & 24.024 & 2.292 \\
1462.1 & 32.078 & 2.936 & 1481.39 & 1449.57 & 15.098 & 0.574 \\
1503.58 & 39.917 & 1.715 & 1536.37 & 1499.72 & 12.912 & 0.451 \\
1556.62 & 56.783 & 2.348 & 1567.23 & 1551.8 & 3.676 & 0.201 \\
& & & & & &
\end{tabular}


THANGAVELU LAKSHMI et al.: Anti oxidant, FTIR, Anti diabetic assay of Acacia catechu seed

\begin{tabular}{|ccccccc|}
\hline 1637.64 & 44.309 & 0.283 & 1638.6 & 1585.55 & 15.572 & 0.132 \\
1652.1 & 41.91 & 3.613 & 1661.75 & 1645.35 & 5.953 & 0.368 \\
1664.64 & 46.523 & 0.912 & 1692.61 & 1622.71 & 9.022 & 0.349 \\
2157.47 & 92.062 & 0.863 & 2222.09 & 2128.54 & 3.055 & 0.2 \\
2852.84 & 34.601 & 3.55 & 2863.45 & 2359.04 & 82.066 & 0.838 \\
2923.25 & 22.368 & 18.908 & 3002.33 & 2864.41 & 66.342 & 13.934 \\
3224.15 & 22.948 & 0.438 & 3228.01 & 3003.3 & 110.894 & 3.084 \\
3245.37 & 22.401 & 0.098 & 3248.27 & 3228.98 & 12.442 & 0.025 \\
3263.7 & 21.967 & 0.212 & 3271.41 & 3249.23 & 14.521 & 0.041 \\
3283.95 & 21.705 & 0.211 & 3290.7 & 3272.38 & 12.11 & 0.043 \\
3303.24 & 21.48 & 0.914 & 3310.95 & 3291.67 & 12.832 & 0.036 \\
3322.53 & 21.253 & 0.185 & 3328.31 & 3311.92 & 10.989 & 0.034 \\
3340.85 & 20.991 & 0.209 & 3347.6 & 3329.28 & 12.368 & 0.039 \\
3359.18 & 20.724 & 0.247 & 3366.89 & 3348.57 & 12.472 & 0.049 \\
3378.47 & 20.616 & 0.189 & 3386.18 & 3367.86 & 12.529 & 0.04 \\
3396.79 & 20.564 & 0.186 & 3407.4 & 3387.15 & 13.87 & 0.038 \\
3419.94 & 20.564 & 0.192 & 3429.58 & 3408.36 & 14.532 & 0.043 \\
3436.33 & 20.724 & 0.058 & 3450.8 & 3434.4 & 11.169 & 0.012 \\
3564.6 & 26.539 & 1.188 & 3641.76 & 3560.75 & 37.873 & 1.515 \\
3646.58 & 46.935 & 2.683 & 3667.8 & 3642.73 & 7.202 & 0.301 \\
3958.1 & 42.491 & 9.95 & 3960.03 & 3944.6 & 3.073 & 0.561 \\
3979.32 & 46.265 & 0.227 & 3988.96 & 3970.64 & 6.114 & 0.019 \\
\hline
\end{tabular}

Table 5 : Alpha Amylase Inhibitory Assay

\begin{tabular}{cc}
\hline Concentration $(\boldsymbol{\mu g})$ & Percentage activity (\%) \\
\hline $\mathbf{1 0 0}$ & $4.71 \pm 0.86$ \\
$\mathbf{2 0 0}$ & $9.23 \pm 0.33300$ \\
$\mathbf{3 0 0}$ & $12.99 \pm 0.46$ \\
$\mathbf{4 0 0}$ & $19.02 \pm 1.82$ \\
$\mathbf{5 0 0}$ & $25.05 \pm 1.18$ \\
$\mathbf{I C}_{\mathbf{5 0}}$ A.catech $\boldsymbol{u}=\mathbf{3 4 1 . 2 0 \pm \mathbf { 1 5 . 3 0 }}$ \\
\hline
\end{tabular}

\section{FTIR spectroscopy}

FTIR Spectroscopy emphasize the presence of the following functional groups present in Acacia catechu ethanolic seed extract at 3400 peak $\mathrm{OH}$ group, 2923 and $2852 \mathrm{C}-\mathrm{H}$ stretching vibrations that are mainly generated by lipids, 2157 peak generates Carboxylic acids, $1652 \mathrm{C}=\mathrm{O}$ (Amide), 1556 Asymmetric stretching for aliphatic and aromatic nitro compounds, 1462, 1374 peak generates Alkanes, $1423 \mathrm{~N}-\mathrm{H}, 1243,1082$ peak generates alkyl halides, 1158 peak aliphatic amines are present, at 1015 and $991 \mathrm{C}-\mathrm{O}$ stretch (Esters) are seen.

The peaks generated in FTIR spectroscopy were depicted in Table 4 and Figure 4.

\section{In vitro Anti diabetic activity}

Treatment of diabetes in patients with insulin-dependent and noninsulin-dependent diabetes, diabetic retinopathy, diabetic peripheral neuropathy was made successful using lots of herbal products. ${ }^{23}$ From the reports on their potential effectiveness against diabetes, it can be assumed that the herbal remedies have a remarkable role to play in the management of diabetes, which needs further exploration for necessary development of drugs and nutraceuticals from natural resources.

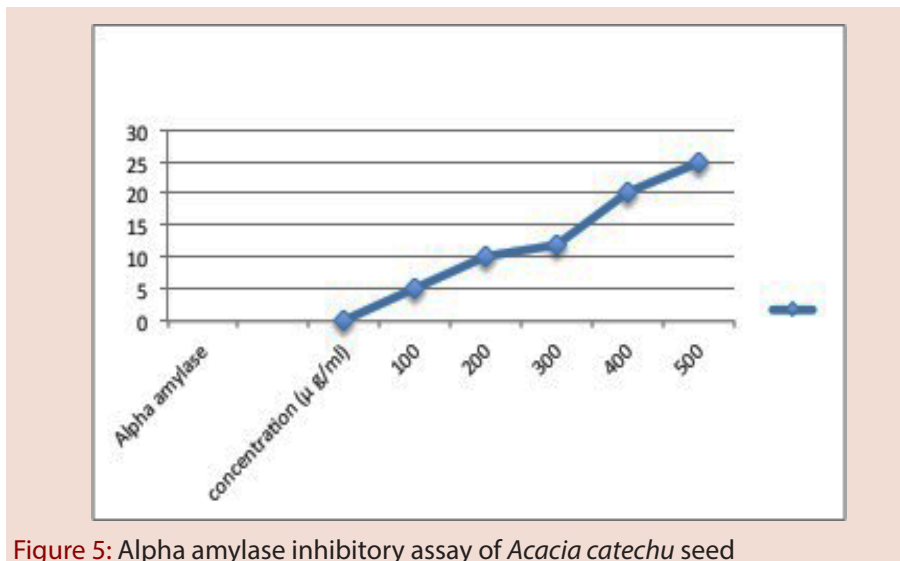

Figure 5: Alpha amylase inhibitory assay of Acacia catechu seed

\section{Alpha amylase and Alpha glucosidase inhibitory assay}

Acacia catechu commonly known as black cutch is used for treatment of diabetes and management of pain and inflammation by the traditional medicinal practitioners of Bangladesh. ${ }^{24}$ Acacia catechu seed extract when tested In vivo in normal albino rats in combination of other extracts exhibited significant Anti-diabetic activity. ${ }^{25}$ Synthetic a-glucosidase inhibitors are used widely but may cause severe gastro intestinal disturbances, ${ }^{26}$ hence the use of natural products have raised to overcome the side effects caused by synthetic drugs.

The in vitro anti-diabetic study was carried to assess the a-glucosidase and $\alpha$-amylase inhibitory activity of the extract to control postprandial hyperglycemia in Type-2 diabetes mellitus patients. ${ }^{27}$

The current study suggest that the presence of polyphenolic compounds of Acacia catechu ethanolic seed extract may have a prominent role in managing Type- 2 diabetes. The $\alpha$-glucosidase and $\alpha$-amylase inhibitory activity of Acacia catechu ethanolic extract, $53.77 \pm 0.86 \%$ and $25.05 \pm$ 
Table 6: Alpha Glucosidase inhibitory assay of Acacia catechu seed

\begin{tabular}{cc}
\hline Concentration $(\mu \mathrm{g})$ & Percentage activity (\%) \\
\hline $\mathbf{1 0 0}$ & $12.01 \pm 3.83$ \\
$\mathbf{2 0 0}$ & $24.34 \pm 6.49$ \\
$\mathbf{3 0 0}$ & $35.62 \pm 3.03$ \\
$\mathbf{4 0 0}$ & $47.63 \pm 4.22$ \\
$\mathbf{5 0 0}$ & $53.77 \pm 0.86$ \\
\hline $\mathbf{I C}_{\mathbf{5 0}}$ A.catechu=187.80 & $\mathbf{4 . 1 5}$ \\
\hline
\end{tabular}

Values are mean \pm SD of triplicate samples.

$1.18 \%$ was confirmed in this study at a concentration of $500 \mu \mathrm{g} / \mathrm{ml} . \mathrm{IC}_{50}$ value for inhibition of $\alpha$-glucosidase activity $187.80 \pm 4.15 \mu \mathrm{g} / \mathrm{ml} ; \mathrm{IC}_{50}$ value for inhibition of $\alpha$-amylase activity $341.20 \pm 15.30 \mu \mathrm{g} / \mathrm{ml}$. Lower the $\mathrm{IC}_{50}$ value better the inhibition activity of the extract tested. Values are expressed as mean \pm SD. It was noted that the $\alpha$-glucosidase activity is comparatively better than $\alpha$-amylase activity.

The percentage inhibition of $\alpha$-glucosidase activity by ethanolic extract of Acacia catechu seed is shown in Table 5 and Figure 5. The percentage inhibition of $\alpha$-amylase activity by ethanolic extract of Acacia catechu seed is shown in Table 6 and Figure 6.

\section{CONCLUSION}

Inhibition of $\alpha$-glucosidase and $\alpha$-amylase enzyme activity leads to a reduction in disaccharide hydrolysis which has beneficial effects on glycemic index control in diabetic patients and can reduce the incidence of post prandial hyperglycemia. As the plant extract was reported for having anti-diabetic activity in vivo, its activity was evaluated in vitro. In conclusion, the present study indicates that Acacia catechu ethanolic seed extract shows prominent antioxidant and anti diabetic activity, The Antidiabetic activity reported is due to the presence of polyphenols in the tested plant extract, and thus the plant extract may provide the biochemical rationale for further animal and clinical trails.

\section{ACKNOWLEDGEMENTS}

Authors are thankful to Dr. Udayaprakash, Marina labs, Nerkundram, Chennai for providing the assistance and Dr. R. Vijayaraghavan, Director of Research, Saveetha University for the able guidance in the study.

\section{CONFLICT OF INTEREST}

The authors declare no conflict of interest.

\section{REFERENCES}

1. Cheeseman KH, Slater TF. Free radicals in medicine. Churchill Livingstone Pub. British Med. Bull. 1993; 49(3): 479-724.

2. Mohd Nur Alam Nusrat Jahan Bristi, Mohd Rafiquzzaman. Review on in vivo and in vitro methods evaluation of antioxidant activity. Saudi Pharmaceutical Journal 2013; 21(2): 143-52.

3. Dou F, Xi M, Wang J, Tian X, Hong L, Tang H, et al. alpha-Glucosidase and alphaamylase inhibitory activities of saponins from traditional Chinese medicines in the treatment of diabetes mellitus. Pharmazie 2013; 68(4): 300-4.

4. Tundis R, Loizzo MR, Menichini F. Natural products as alpha-amylase and alphaglucosidase inhibitors and their hypoglycemic potential in the treatment of diabetes: an update. Mini Reviews in Medicinal Chemistry 2010; 10(4): 315-31.

5. Dwek RA, Butters TD, Platt FM, Zitzmann N. Targeting glycosylation as a therapeutic approach. Nat. Rev. Drug Discov. 2002; 1(1): 65-75.

6. Chiasson JL, Josse RG, Gomis R, Hanefeld M, Karasik A, Laakso M. Acarbose for prevention of type 2 diabetes mellitus: the STOP-NIDDM randomised trial. Lancet 2002; 359(9323): 2072-7.

7. Baron AD. Postprandial hyperglycemia and -glucosidase inhibi-tors. Diabetes Res. Clin. Pract. 1998; 40(1): S51-5.

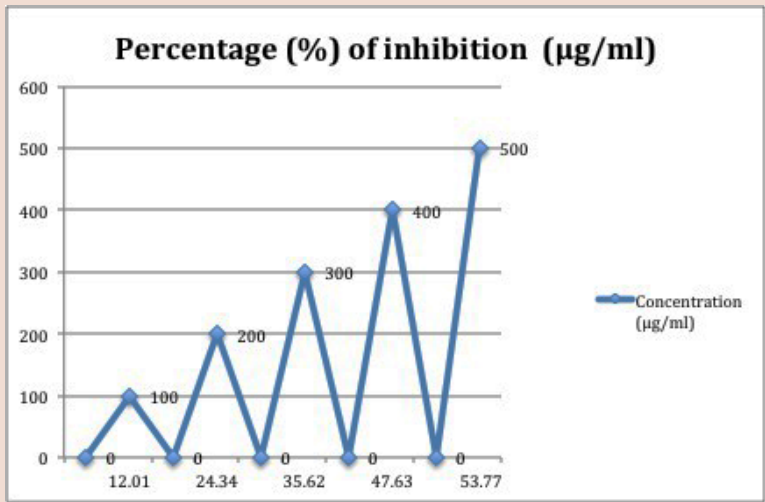

Figure 6: Alpha glucosidase inhibitory assay of Acacia catechu seed

8. Singh KN, Lal B. Note on traditional uses of Khair (Acacia catechu Willd.) by inhabitants of shivalik range of western Himalaya, Ethnobotanical Leaflets 2006; 10(1): 109-12.

9. Naik GH, Priyadarsini KI, Satav JG, Banavalikar MM, Sohoni DP, Biyani MK, et al. Comparative antioxidant activity of individual herbal components used in Ayurvedic medicine. Phytochem. 2003; 63(1): 97-104.

10. Anonymous Indian Herbal Pharmacopoeia. Revised new edition 2002, Indian Drug Manufacturer's Association, Mumbai 2002; 11(1): 13-6.

11. Lakshmi T, Anitha R, Geetha RV. Acacia catechu willd-A gift from ayurveda to mankind-A Review. T. Ph. Res. 2011; 5(2): 273-93.

12. Lakshmi T, Aravindkumar S. Preliminary phytochemical analysis and In vitro Antibacterial activity of Acacia catechu willd Bark against Streptococcus mitis, Streptococcus sanguis and Lactobacillus acidophilus. International Journal of Phytomedicine 2011; 3(4): 579-84.

13. Evans WC. Trease and Evans' Pharmacognosy 14 Edn. WB. Saunders Company, London; 1996

14. KalitaTapan BK, PalTK, Kalita R. Estimation of total flavonoids content (TFC) and antioxidant activities of methanolic whole plant extract of Biophytum sensitivum Linn. J. Drug Delivery Ther. 2013; 3(4): 33-7.

15. Wan C, Yu Y, Zhou S, Liu W, Tian S, Cao S. Antioxidant activity and free radicalscavenging capacity of Gynura divaricata leaf extracts at different temperatures. Pharmacogn. Mag. 2011; 7(25): 40-5.

16. Janakiraman N, Sahaya Sathish S, Johnson M. UV-VIS and FTIR Spectroscopic Studies on Peristrophe bicalyculata (Retz.) Nees. Asian Journal of Pharmaceutical and Clinical Research 2011; 4(4): 125-9.

17. Miller GL. Use of dinitro salicylic acid reagent for determination of reducing sugar. Anal. Chem. 1959; 31(3): 426-8.

18. Anis Z, Sulaiman O, Hashim R, Mehdi SH, Ghalib RM. Radical scavenging activity: total phenol content and antifungal activity of Cinnamomum iners wood. Iranica J. Energy Environ. 2012; 3(5): 74-8.

19. Deepa S, Ramesh KP, Swarna VK, Rao JR, Chandrasekaran B. Antioxidant and cytotoxic effects of methanolic extract of Salicornia brachiata L. in HepG2 cells. Int. J. Res. Pharm. Sci. 2013; 4(4): 512-7.

20. Kalita, Tapan BK, Pal TK, Kalita R. Estimation of total flavonoids content (TFC) and antioxidant activities of methanolic whole plant extract of Biophytum sensitivum Linn. J. Drug Delivery Ther. 2013; 3(4): 33-7.

21. Udayaprakash NK, Bhuvaneswari S, Sripriya N, Prameela L, Bhagya R, Radhika $B$, et al. Antioxidant activity of common plants of northern Tamil Nadu, India. Int J. Pharm. Pharm. Sci. 2014; 6(1): 128-32.

22. Siddhuraju P, Becker K. Antioxidant properties of various solvent extracts of to tal phenolic constituents from three different agroclimatic origins of drumstick tree (Moringaoleifera Lam.) leaves. J. Agric. Food Chem. 2003; 51(8): 2144-55.

23. Wang Y, Xiang L, Wang C, Tang C, He X. Antidiabetic and Antioxidant Effects and Phytochemicals of Mulberry Fruit (Morus alba L.) Polyphenol Enhanced Extract. plos one. 2013; 8(7): e71144

24. Mohammed Rahmatullah, MarazHossain, Fatema Islam. Antihyperglycemic and Antinociceptive Activity Evaluation of 'Khoyer' Prepared from Boiling the Wood of Acacia Catechu in Water. Afr J Tradit Complement Altern Med. 2013; 10(4): 1-5.

25. Singh KN, Mittal RK, Barthwal KC. Hypoglycemic activity of Acacia catechu, Acacia suma, and Albizzia odoratissima seed diets in normal albino rats. Indian Journal of Medical Research 1976; 64(5): 754-7.

26. Kajaria D, Ranjana, Tripathi J, Tripathi YB, Tiwari S. In vitro $\alpha$ amylase and glycosidase inhibitory effect of ethanolic extract of antiasthmatic drug-Shirishadi. Journal of Advanced Pharmaceutical Technology and Research 2013; 4(4): 206-9.

27. Jayasri MA, Radha A, Mathew TL. $\alpha$ - amylase and $\alpha$-glucosidase inhibitory activity of Costus pictus D. DON in the management of diabetes. Journal of Herbal Medicine and Toxicology 2009; 3(1): 91-4. 


\section{ABOUT AUTHORS}

Ms. Thangavelu Lakshmi: Is an Assistant professor at the Department of Pharmacology, Saveetha Dental College and Hospitals, Saveetha University, Chennai, Tamilnadu, India. Her research interest includes Pharmacognosy, Pharmacology, Phytotherapy, Toxicology, and Pharmaceutical sciences. She has more than 50 nos. of Publications in peer reviewed indexed national and international journals. She is a peer reviewer in various journals. She is a IRCA registered Lead auditor for QMS ISO 9001:2008 certification. She is an editorial board member in International journal of pharmacy and pharmaceutical sciences, Internationale pharmaceutica sciencia, IBIMA publishers, USA. Ms.Lakshmi is also alife member of Indian pharmacological society, Society of Pharmaceutical education and research (SPER), Indian association of biomedical scientist (IABMS), Society of Toxicology (STOX) and Society of Ethno pharmacology.

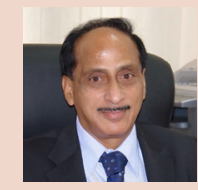

Ramasamy Rajendran: Is owing two herbal companies, Green Chem in Bangalore and Natsyn catalyst in Namakkal. He has done his post graduation in biochemistry. He is an eminent person holding about 26 patents globally on herbals. He has received more than 12 National/ International Awards to his credit. He also signed MOU with many Universities/colleges in India and abroad. He has more than 20 no. Paper publications as an co-author in peer reviewed indexed national/international journals. He published a chapter "Role of Caralluma fimbriata in weight management "in a book "Obesity, Epidemiology, Pathophysiology and Prevention" by Debasis Bagchi, Harry G.Preuss (CRC Press), 2007. He also co authored for a book "Boswellin, The Anti Inflammatory Phytonutrient," Published by Sabinsa Corporation, USA.

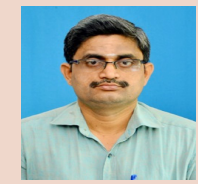

Rathinam Thirumalaikumaran: Is a Doctorate in Pharmacy from Sri Ramachandra University. He is an is an Assistant professor at the Department of Pharmacognosy, Faculty of Pharmacy, Sri Ramachandra University, Chennai. He has an vast experience of about 20 years in teaching and has a publication of 25 no. in peer reviewed indexed national and international journals. He is an editor in various Pharma journals. Member in APTI and SFE. A book is in under process in Pharmacognosy. 